\title{
Knowledge of cardiovascular disease risk factors and the risk of death in middle-aged residents of Krakow
}

\author{
Anna Waśniowska ${ }^{1}$, Magdalena Kozela ${ }^{2}$, Piotr Podolec ${ }^{3}$, Andrzej Pająk ${ }^{2}$ \\ 'Department of Diagnostics, John Paul II Hospital, Krakow, Poland \\ ${ }^{2}$ Department of Epidemiology and Population Studies, Institute of Public Health, Faculty of Health Sciences, Jagiellonian University \\ Medical College, Krakow, Poland \\ ${ }^{3}$ Department of Cardiac and Vascular Diseases, Jagiellonian University Medical College, John Paul II Hospital, Krakow, Poland
}

\begin{abstract}
A bstract
Background: Providing knowledge of cardiovascular disease (CVD) risk factors is the main component of prevention programmes, which aim to reduce the exposure to these factors and decrease CVD incidence and mortality. However, evidence linking knowledge of CVD risk factors and the risk of death is scarce.

Aim: The aim of the study was to assess the relation between knowledge of CVD risk factors and the risk of death from all causes in middle-aged residents of Krakow and to assess whether this relation depends on the level of education.

Methods: The study sample included 1756 men and 1788 women selected from a population of Krakow residents at age 45-64 years. Knowledge of CVD risk factors was assessed for every risk factor separately using a standard questionnaire. Results were summarised by calculating the "knowledge index" (from -15 to 15 points). Information on deaths was obtained from the registry of Krakow residents. Cox proportional hazards model was used to assess the relation between knowledge of CVD risk factors and all-cause mortality.

Results: At baseline examination the participation rate was $66 \%$ in men and $65 \%$ in women. The proportion of participants with secondary or higher education was $61 \%$ in men and $66 \%$ in women. Distribution of knowledge index was right skewed, and the median was 11 (interquartile range: 9-13) in both sexes. Median time of follow-up was 14.35 years (interquartile range: 14.30-14.39). There were 307 deaths in men and in women. Men with a low level of knowledge of risk factors had a higher risk of death. However, adjustment for education attenuated the association. After stratification by the level of education, in men with secondary education or higher, an inverse relation between the knowledge of CVD risk factors and the risk of death was found. In this group, men with a low level of knowledge of CVD risk factors had about a $60 \%$ higher risk of death, compared to men with high knowledge. In men with low education and in women the risk of death was not associated with knowledge of risk factors.

Conclusions: In a Krakow population characterised by a high proportion of residents with secondary or higher education, the association between knowledge of CVD risk factors and the risk of death depended on sex and the level of education. A lower level of knowledge of risk factors was associated with a higher risk of death only in men with secondary or higher education. Key words: risk factors, education, cohort study
\end{abstract}

Kardiol Pol 2017; 75, 4: 386-394

\section{INTRODUCTION}

In Poland, since 1992, mortality from diseases of the circulatory system has been decreasing systematically. Nevertheless, these diseases remain the leading cause of mortality, accounting for over $45 \%$ of all deaths [1]. It is known that cardiovascular disease (CVD) can be prevented by eliminating the known risk factors, which can be achieved through lifestyle changes or use of pharmacotherapy [2]. Reduction

Address for correspondence:

Anna Waśniowska, MD, Department of Diagnostics, John Paul II Hospital, ul. Prądnicka 80, 31-202 Kraków, Poland, e-mail: anwasniowska@gmail.com

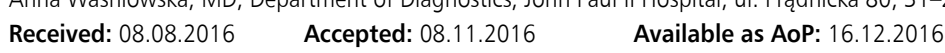

Kardiologia Polska Copyright (C) Polskie Towarzystwo Kardiologiczne 2017 
of exposure to CVD risk factors was confirmed to have the greatest impact on reduction of mortality from coronary heart disease in many countries, including Poland [3-5]. However, exposure to classic risk factors is still frequent. For example, dyslipidaemia occurs in $80 \%$ of the Polish adult population [6].

In the European guidelines on CVD prevention in clinical practice, media and health education, as a component of comprehensive, multicomponent prevention programmes, are considered as one of the main tools to achieve beneficial lifestyle changes and long-term use of optimal pharmacotherapy. Population education programmes are of particular importance in the population-based approach [2]. Indeed, in Poland, the majority of the population receives information on risk factors mainly from the mass media [7]. Consequently, the benefits of education may be largely dependent on access to such sources of information and the degree of perception of this kind of information.

Results of the analysis presented recently in the report of the Polish Government Population Council confirm the results of studies from other countries, in which CVD mortality was related to the level of education and indicate that the reduction in mortality was smaller in the group with low education [8-11]. This contributed to an increase in health inequalities, which are also confirmed by observations on the territorial and social differences in life expectancy in Poland [1, 8].

Higher education is often associated with a higher social and economic status and with better access to medical care. According to the recent guidelines on CVD prevention, low social status is regarded as an independent CVD risk factor. The relation between education, low social status, and CVD risk was also confirmed in Polish studies [12]. Low education may be associated with other psychological factors that reflect the so-called chronic psychosocial stress, which increases CVD risk [13, 14]. However, there is no doubt that the lower CVD risk in people with higher education can be at least partly explained by better knowledge about the disease, its symptoms, and risk factors. As a result, better educated people might have a healthier lifestyle and might be more likely to follow medical recommendations. Nevertheless, it is not described to what extent the relation between education and the risk of death can be explained by the level of knowledge and to what extent education is a marker of a social position.

The aim of this study was to assess the relation between knowledge of CVD risk factors and the risk of death from all causes in middle-aged residents of Krakow and to assess whether this relation depends on the level of education.

\section{METHODS}

The study sample included 3544 persons (1756 men and 1788 women), participants of the HAPIEE (Health, Alcohol, and Psychosocial factors In Eastern Europe) pilot study, selected from Krakow's residents at age 45-64 years. Random sampling was conducted in the sex and 10-year age groups in four main districts of the city.
The methods used in the HAPIEE pilot study were described earlier [15]. Below, a brief description relevant to the present paper is given.

Baseline examination included interviews carried out in participants' homes by trained interviewers. Then, the participants were invited to the clinic for a physical examination and blood collection. Participants were interviewed using a standard questionnaire, which included information on the level of education (categories of elementary, vocational, secondary or university), marital status, occupational status, knowledge of CVD risk factors, smoking, and physical activity. Knowledge of CVD risk factors was assessed using 15 questions. Respondents were asked to indicate which characteristic, disease, or health behaviour may predispose someone to have a heart attack by selecting one of the possible answers 'yes', 'no', or 'don't know'. The answers were scored: 1 - correct answer, 0 - don't know, and -1 - incorrect answer. The results were summarised by calculating the 'knowledge index' (from -15 to 15 points). Classification into the 'high' and 'low' level of knowledge of CVD risk factors was done using the cut-off point equal to the median ( $\mathrm{Me}=11$ ). Participants smoking at least one cigarette a day or smoking occasionally were considered as current smokers. Those who had smoked in the past but stopped were classified as ex-smokers and the remaining persons were classified as never smokers. Respondents were classified into three categories of physical activity: low (inactive whole week), moderate (modest physical activity for majority of weeks), and high (intensive physical activity for at least 20 min once a week or more).

Height and weight were measured in the vertical position using medical scales with a ruler. Body mass index was calculated using the formula: body mass $[\mathrm{kg}] /\left(\right.$ height $\left.\left[\mathrm{m}^{2}\right]\right)$. Blood pressure was taken on the right arm of a seated person, after at least 5 min of rest, using a mercury manometer. Out of three measurements taken in 1-min intervals, the mean of the second and third was used in the analysis. Blood for biochemical analysis was collected by venipuncture from participants in fasting state, sitting position, with limited use of tourniquet $(<1 \mathrm{~min}$ ). Total blood cholesterol was assessed using the oxidation method with a MP3 Boehringer Mannheim chemical reagent kit in a Technicon RA-1000 automatic analyser. Total serum high-density lipoprotein was determined with prior precipitation of low-density lipoprotein and very low-density lipoprotein fractions using heparin $\mathrm{MnCl}_{2}$. The concentration of triglycerides in blood serum was determined using the oxidation method with a TG 30 Cormay chemical reagent kit in a Technicon RA-1000 automatic analyser. Blood glucose concentration was assessed using the GOD-PAT method (enzymatic - colorimetric with glucose oxidation, without deproteinisation) using Hitachi 911 and 917 machines.

Information on participants' deaths and the dates was obtained from the registry of residents. Participants were followed for mortality for up to 15 years. 
Table 1. Age, education, marital status, and occupational status by sex

\begin{tabular}{|c|c|c|c|c|c|}
\hline & \multicolumn{2}{|c|}{ Men } & \multicolumn{2}{|c|}{ Women } & \multirow[t]{2}{*}{$\mathbf{p}$} \\
\hline & $\mathbf{N}$ & $\%$ & $\mathbf{N}$ & $\%$ & \\
\hline Age [years] & \multicolumn{2}{|c|}{$54.51 \pm 5.75$} & \multicolumn{2}{|c|}{$53.93 \pm 5.76$} & 0.0146 \\
\hline Education: & & & & & $<0.001$ \\
\hline Primary or vocational & 433 & 39.19 & 380 & 34.11 & \\
\hline Secondary & 346 & 31.31 & 453 & 40.66 & \\
\hline University & 326 & 29.50 & 281 & 25.22 & \\
\hline Marital status: & & & & & $<0.001$ \\
\hline Married or cohabiting & 967 & 87.51 & 790 & 70.98 & \\
\hline Single or widowed & 138 & 12.49 & 323 & 29.02 & \\
\hline Occupational status: & & & & & $<0.001$ \\
\hline Active & 631 & 54.82 & 542 & 46.89 & \\
\hline Inactive & 520 & 45.18 & 614 & 53.11 & \\
\hline
\end{tabular}

\section{Statistical analysis}

Differences between the studied groups was tested using $\chi^{2}$, t test, and U-Mann-Whitney test. The probability of survival was presented as Kaplan-Meier curves. The Cox proportional hazards model was used to assess the relation between the knowledge of CVD risk factors and all-cause mortality. Results are presented as hazard ratios (HR) with 95\% confidence intervals $(95 \% \mathrm{Cl})$. Statistical significance was accepted at the level of $p<0.05$. Analyses were performed using STATA ver. 12.1 (StataCorp LP, TX, USA).

\section{RESULTS}

There were 1152 men and 1158 women included in the analysis. Participation rate was similar in men and in women: $66 \%$ and $65 \%$, respectively. In men, the mean age was $55 \pm 5.8$ years and in women $54 \pm 5.8$ years. There were 91 persons who did not provide information on the level of education and were excluded from the multivariate models that required information on education. The percentage of participants with secondary and university education was high in both sexes. Only 39\% of men and 34\% of women had elementary or vocational education, $31 \%$ of men and $41 \%$ of women had secondary education, and $30 \%$ of men and $25 \%$ of women had university education. Compared to women, men were more likely to be married (88\% vs. $71 \%$, respectively, $\mathrm{p}<0.001)$ and occupationally active $(55 \%$ vs. $47 \%$, respectively, $p<0.001$; Table 1 ). Most risk factors (smoking, hypertension, high level of blood cholesterol, obesity, fatty diet) were identified correctly by at least $90 \%$ of participants. However, some risk factors (sedentary lifestyle, alcohol abuse, diabetes, and family history of CVD) were recognised less frequently. A noticeable proportion of participants classified incorrectly the protective factors (low blood pressure) or lifestyle characteristics (smoking cessation and physical activity) as CVD risk factors (Table 2). Distribution of knowledge index was right skewed, and the median was 11 (interquartile range: 9-13) in both sexes (Fig. 1). The median time of follow-up was 14.35 years (interquartile range: $14.30-14.39$ ). Survival analysis included 31,188 person years. There were 211 deaths in men and 96 in women. Men with low level of knowledge of CVD risk factors had a higher risk of death (Fig. 2). The relation was significant after adjustment for occupational activity and marital status. However, adjustment for education attenuated the association (Table 3). After stratification by education, in men with secondary or higher education, an inverse relation between the knowledge of risk factors and the risk of death was found, which was independent of age. In this group, men with a low level of knowledge of CVD risk factors had about $60 \%$ higher risk of death, compared to men with high knowledge $(\mathrm{HR}=1.60$, 95\% Cl 1.04-2.48) (Table 4). Furthermore, in this group, the differences in the exposure to CVD risk factors were in favour of persons with higher knowledge but were not statistically significant (Table 5). In men with low education and in women the risk of death was not associated with knowledge of CVD risk factors.

\section{DISCUSSION}

In middle-aged persons, in whom the knowledge of CVD risk factors was common, but superficial (many respondents incorrectly classified CVD protective factors as CVD risk factors), low level of knowledge of CVD risk factors was associated with a higher risk of death only in men with secondary or higher education.

Decrease in all-cause mortality is ultimately the most important argument, which verifies the benefits from the reduction of the exposure studied. However, healthy lifestyle, i.e. a favourable diet, maintaining physical activity, not 
Table 2. Proportion of participants with knowledge of cardiovascular disease risk factors by sex

\begin{tabular}{|c|c|c|c|c|c|c|}
\hline \multirow[t]{2}{*}{ Risk factors } & \multicolumn{3}{|c|}{ Men } & \multicolumn{3}{|c|}{ Women } \\
\hline & $\begin{array}{c}\text { Correct } \\
\text { answers (\%) }\end{array}$ & $\begin{array}{c}\text { Incorrect } \\
\text { answers (\%) }\end{array}$ & $\begin{array}{c}\text { Don't know } \\
(\%)\end{array}$ & $\begin{array}{c}\text { Correct } \\
\text { answers (\%) }\end{array}$ & $\begin{array}{c}\text { Incorrect } \\
\text { answers (\%) }\end{array}$ & $\begin{array}{c}\text { Don't know } \\
(\%)\end{array}$ \\
\hline Smoking & 95 & 3 & 2 & 96 & 2 & 2 \\
\hline Smoking cessation & 59 & 15 & 25 & 55 & 17 & 28 \\
\hline Hypertension & 91 & 2 & 6 & 93 & 3 & 4 \\
\hline Low blood pressure & 48 & 22 & 30 & 46 & 24 & 30 \\
\hline High cholesterol level & 90 & 2 & 8 & 91 & 2 & 7 \\
\hline Low cholesterol level & 70 & 4 & 26 & 68 & 5 & 28 \\
\hline Obesity & 96 & 1 & 3 & 97 & 1 & 3 \\
\hline Slim body & 83 & 4 & 13 & 82 & 4 & 14 \\
\hline Sedentary lifestyle & 85 & 9 & 6 & 84 & 7 & 9 \\
\hline Physical activity & 75 & 17 & 8 & 74 & 16 & 10 \\
\hline Fatty diet & 91 & 3 & 6 & 94 & 3 & 3 \\
\hline Low-fat diet & 88 & 2 & 10 & 90 & 1 & 8 \\
\hline Alcohol abuse & 87 & 7 & 6 & 89 & 4 & 7 \\
\hline Family history of heart disease & 68 & 15 & 17 & 74 & 12 & 14 \\
\hline Diabetes & 64 & 5 & 31 & 62 & 7 & 30 \\
\hline
\end{tabular}

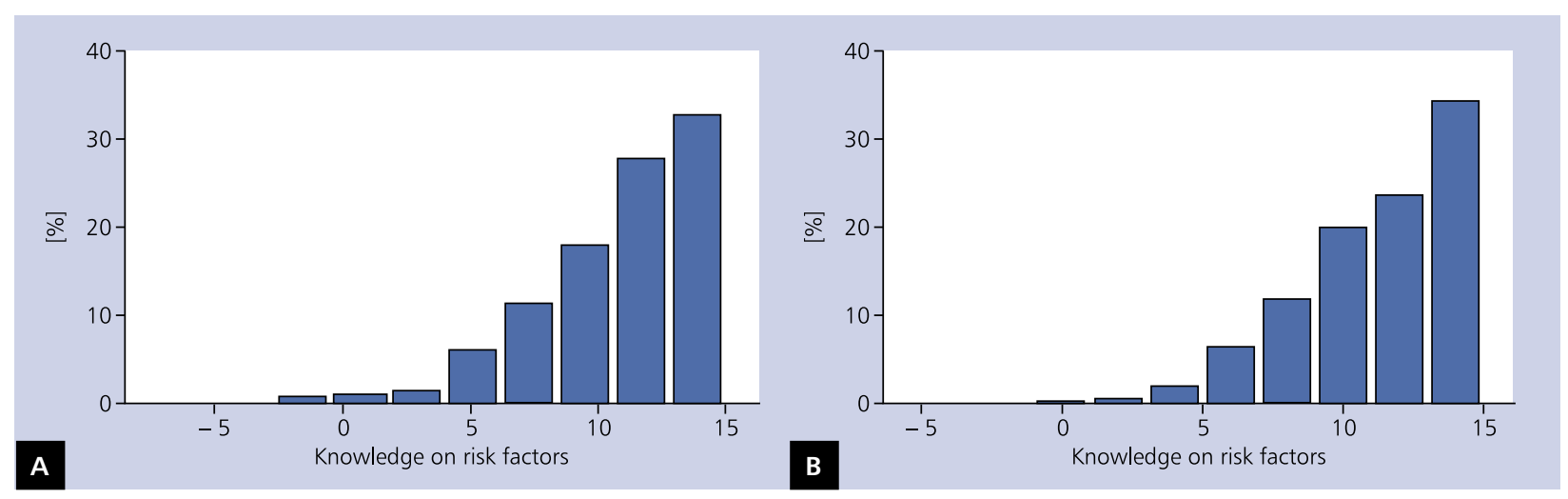

Figure 1. Distribution of knowledge of cardiovascular disease (CVD) risk factors (knowledge index) in men (A) and in women (B)

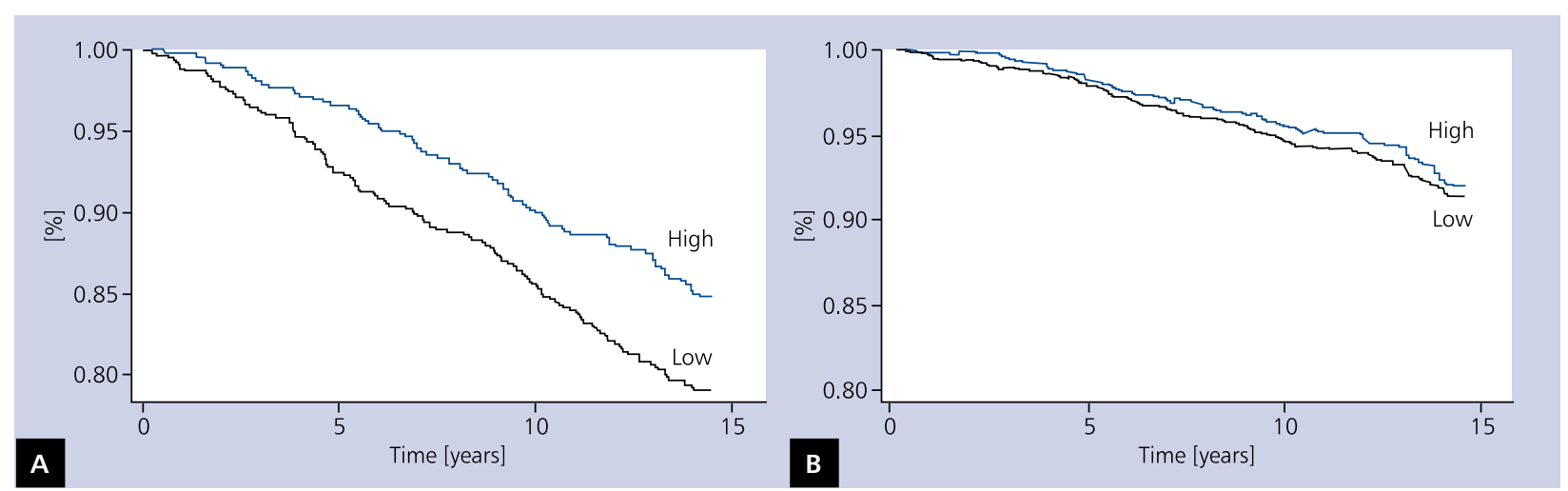

Figure 2. Kaplan-Meier curves by level of knowledge of cardiovascular disease (CVD) risk factors in men (A) and in women (B) (high - knowledge index $>11$, low - knowledge index $\leq 11$ ) 
Table 3. Relationship between level of knowledge of cardiovascular disease risk factors and risk of death from all causes by sex

\begin{tabular}{|c|c|c|c|c|}
\hline & $\mathrm{HR}^{\mathrm{a}}(95 \% \mathrm{Cl})$ & $\mathrm{HR}^{\mathrm{b}}(95 \% \mathrm{Cl})$ & $\mathrm{HR}^{\mathrm{c}}(95 \% \mathrm{Cl})$ & $\operatorname{HR}^{\mathrm{d}}(95 \% \mathrm{Cl})$ \\
\hline \multicolumn{5}{|l|}{ Men: } \\
\hline High & 1.00 & 1.00 & 1.00 & 1.00 \\
\hline Low & $1.41(1.07-1.87)$ & $1.18(0.88-1.57)$ & $1.44(1.09-1.91)$ & $1.33(1.00-1.75)$ \\
\hline \multicolumn{5}{|l|}{ Women: } \\
\hline High & 1.00 & 1.00 & 1.00 & 1.00 \\
\hline Low & $1.09(0.73-1.63)$ & $0.96(0.63-1.46)$ & $1.09(0.72-1.64)$ & $1.07(0.72-1.60)$ \\
\hline
\end{tabular}

${ }^{a}$ Adjusted for age; ${ }^{b}$ Adjusted for age and education; 'Adjusted for age and marital status; ${ }^{d}$ Adjusted for age and occupational status;

$\mathrm{Cl}$ - confidence interval; HR - hazard ratio

Table 4. Relationship between level of knowledge of cardiovascular disease risk factors and risk of death from all causes by education and sex

\begin{tabular}{lcc|} 
& \multicolumn{2}{c}{ Education } \\
\cline { 2 - 3 } & $\begin{array}{c}\text { Secondary and university } \\
\text { HR }(95 \% \mathrm{Cl})\end{array}$ & $\begin{array}{c}\text { Primary and vocational } \\
\text { HR }(95 \% \mathrm{Cl})\end{array}$ \\
\hline Men: & 1.00 & 1.00 \\
High & $1.60(1.04-2.48)$ & $0.92(0.63-1.34)$ \\
Low & & 1.00 \\
Women: & 1.00 & $1.07(0.57-2.01)$ \\
High & $0.88(0.50-1.56)$ & \\
Low &
\end{tabular}

$\mathrm{Cl}$ - confidence interval; HR - hazard ratio

smoking, weight control, and avoiding stress, decreases risk of CVD, which is the cause of about half of all deaths in Poland [1]. It is possible that the relationship between knowledge of risk factors and CVD, may largely explain the relationship between the knowledge and all-cause mortality, especially since it has been shown that CVD is the main cause of shorter life expectancy in Poland compared to European Union countries from before extension in May 2004 [8]. However, it should be considered that CVD risk factors influence overall health, for example increasing the risk of cancer - the second most common cause of death in Poland, and other important causes of deaths [1]. Therefore, further research is needed to assess the extent to which knowledge of CVD risk factors influence the risk of CVD and to what extent the relation between knowledge and all-cause mortality could be explained in another way.

Compared with samples from other countries, the proportion of participants of the present study, who identified CVD risk factors correctly at baseline, was high. For example, in more recent Italian and American cross-sectional studies that used similar methods, smoking, hypertension, and hypercholesterolaemia were indicated as risk factors by less than $90 \%$ of persons $[16,17]$. However, our report is in accordance with findings of a large cross-sectional study (WOBASZ) that pointed out that the knowledge of CVD prevention is not profound in the Polish population and in which the level of knowledge of CVD prevention methods was strongly related to education and other socio-economic factors, but not to exposure to risk factors $[18,19]$. To the best of our knowledge, our study is the only one that has addressed directly the question of whether the knowledge of risk factors is related to risk of death from all causes and whether this relation differs by education groups. However, a relation between knowledge of CVD and of its prevention methods with all-cause mortality was already described [20].

Despite clear strengths of the study, i.e. cohort design, studied sample that was representative of a population of residents of a large town, long follow-up time, and use of standardised methods, some limitations in the interpretation of the results should be considered. Firstly, a relatively small studied group resulted in a low number of deaths observed, and consequently, the sample had low statistical power. This might explain the insignificant estimates in women. Secondly, the assessment of the respondents' knowledge was made only at baseline. It was not assessed whether and to what extent the knowledge was changing overtime and how these changes could affect the risk of death. In a study of American women, knowledge of CVD as the leading cause of death almost doubled between 1997 and 2009 [21]. In the last decade, in Poland, people have been receiving information on CVD risk factors through mass-media and other forms of population-based approaches. It is likely that knowledge of CVD risks in our respondents has also increased. However, it is difficult to predict whether this effect was equal in men and in women, and in all education groups. Thirdly, it should be noted that the method used in this study (participants had to indicate risk factors from the written list of the factors) allowed assessment of the knowledge on a low level of operability. Consequently, the respondents appeared to have knowledge of risk factors more frequently than in the other studies, in which open questions were used $[22,23]$, but on the other hand, the relation between the knowledge of CVD risk factors and risk of death could be weaker. 
Table 5. Distribution of cardiovascular disease (CVD) risk factors by education and by the level of knowledge of CVD risk factors in men and in women

\begin{tabular}{|c|c|c|c|c|c|c|}
\hline & \multicolumn{2}{|c|}{$\begin{array}{c}\text { Secondary and university } \\
\text { education }\end{array}$} & \multirow[t]{2}{*}{$\mathbf{p}$} & \multicolumn{2}{|c|}{$\begin{array}{c}\text { Primary and vocational } \\
\text { education }\end{array}$} & \multirow[t]{2}{*}{$\mathbf{p}$} \\
\hline & High & Low & & High & Low & \\
\hline \multicolumn{7}{|l|}{ Men } \\
\hline BMI $\left[\mathrm{kg} / \mathrm{m}^{2}\right]( \pm \mathrm{SD})$ & $27.6(4.04)$ & $27.7(4.36)$ & 0.661 & $28.3(4.55)$ & $27.7(4.49)$ & 0.247 \\
\hline $\mathrm{SBP}[\mathrm{mm} \mathrm{Hg}]( \pm \mathrm{SD})$ & $138(20.7)$ & $136(20.1)$ & 0.452 & $143(23.0)$ & $143(24.7)$ & 0.906 \\
\hline $\mathrm{DBP}[\mathrm{mm} \mathrm{Hg}]( \pm \mathrm{SD})$ & $89(12.0)$ & $88(11.5)$ & 0.606 & $90(11.7)$ & $90(13.0)$ & 0.776 \\
\hline $\mathrm{TC}[\mathrm{mmol} / \mathrm{L}]( \pm \mathrm{SD})$ & $5.6(1.02)$ & $5.7(1.05)$ & 0.232 & $5.6(1.14)$ & $5.7(0.93)$ & 0.402 \\
\hline $\mathrm{HDL}-\mathrm{C}[\mathrm{mmol} / \mathrm{L}]( \pm \mathrm{SD})$ & $1.38(0.312)$ & $1.38(0.308)$ & 0.999 & $1.40(0.334)$ & $1.44(0.398)$ & 0.424 \\
\hline LDL-C mmol/l] ( $\pm S D)$ & $3.5(0.91)$ & $3.6(0.93)$ & 0.100 & $3.4(0.99)$ & $3.5(0.89)$ & 0.584 \\
\hline Glucose [mmol/L], Me (IR) & $5.2(4.8-5.9)$ & $5.2(4.8-5.9)$ & 0.964 & $5.2(4.8-5.9)$ & $5.4(4.8-6)$ & 0.522 \\
\hline $\mathrm{TG}[\mathrm{mmol} / \mathrm{L}], \mathrm{Me}(\mathrm{IR})$ & $1.36(0.94-2.05)$ & $1.37(1.01-2.07)$ & 0.697 & $1.38(0.94-1.87)$ & $1.41(1.02-1.98)$ & 0.232 \\
\hline Smoking: & & & 0.512 & & & 0.460 \\
\hline Current & $129(35.93 \%)$ & $122(40.26 \%)$ & & $66(48.53 \%)$ & $161(54.58 \%)$ & \\
\hline Ex-smoker & $134(37.33 \%)$ & $107(35.31 \%)$ & & $47(34.56 \%)$ & $86(29.15 \%)$ & \\
\hline Never & $96(26.74 \%)$ & $74(24.42 \%)$ & & $23(16.91 \%)$ & $48(16.27 \%)$ & \\
\hline Physical activity: & & & 0.413 & & & 0.940 \\
\hline Low & $32(8.96 \%)$ & $36(12.04 \%)$ & & $26(19.40 \%)$ & $52(18.12 \%)$ & \\
\hline Moderate & $202(56.58 \%)$ & $167(55.85 \%)$ & & $87(64.93 \%)$ & $191(66.55 \%)$ & \\
\hline High & $123(34.45 \%)$ & $96(32.11 \%)$ & & $21(15.67 \%)$ & $44(15.33 \%)$ & \\
\hline \multicolumn{7}{|l|}{ Women } \\
\hline BMI $\left[\mathrm{kg} / \mathrm{m}^{2}\right]( \pm \mathrm{SD})$ & $27.8(5.08)$ & $28.2(4.96)$ & 0.262 & $29.7(5.38)$ & $29.8(5.55)$ & 0.838 \\
\hline $\mathrm{SBP}[\mathrm{mm} \mathrm{Hg}]( \pm \mathrm{SD})$ & $133(20.7)$ & $134(20.8)$ & 0.617 & $138(22.7)$ & $137(23.4)$ & 0.570 \\
\hline $\mathrm{DBP}[\mathrm{mm} \mathrm{Hg}]( \pm \mathrm{SD})$ & $85(11.5)$ & $86(12.0)$ & 0.451 & $86(12.2)$ & $85(11.7)$ & 0.710 \\
\hline $\mathrm{TC}[\mathrm{mmol} / \mathrm{L}]( \pm \mathrm{SD})$ & $5.8(1.11)$ & $5.8(0.96)$ & 0.710 & $5.7(1.07)$ & $5.9(1.03)$ & 0.169 \\
\hline $\mathrm{HDL}-\mathrm{C}[\mathrm{mmol} / \mathrm{L}]( \pm \mathrm{SD})$ & $1.64(0.395)$ & $1.59(0.371)$ & 0.091 & $1.54(0.336)$ & $1.53(0.386)$ & 0.747 \\
\hline LDL-C mmol/L] ( $\pm S D)$ & $3.6(1.01)$ & $3.6(0.87)$ & 0.879 & $3.6(0.95)$ & $3.7(0.94)$ & 0.380 \\
\hline Glucose [mmol/L], Me (IR) & $4.9(4.4-5.5)$ & $4.9(4.5-5.6)$ & 0.228 & $5.1(4.5-5.7)$ & $5(4.5-5.6)$ & 0.600 \\
\hline TG [mmol/l], Me (IR) & $1.17(0.83-1.65)$ & $1.33(0.94-1.84)$ & 0.011 & $1.26(0.83-1.87)$ & $1.38(0.93-1.88)$ & 0.265 \\
\hline Smoking: & & & 0.358 & & & 0.321 \\
\hline Current & $121(31.03 \%)$ & $114(34.23 \%)$ & & 37 (29.84\%) & 95 (37.55\%) & \\
\hline Ex-smoker & $95(24.36 \%)$ & $67(20.12 \%)$ & & $21(16.94 \%)$ & $41(16.21 \%)$ & \\
\hline Never & $174(44.62 \%)$ & 152 (45.65\%) & & 66 (53.23\%) & 117 (46.25\%) & \\
\hline Physical activity: & & & 0.062 & & & 0.140 \\
\hline Low & $54(14.06 \%)$ & $58(18.07 \%)$ & & $21(17.07 \%)$ & $55(21.91 \%)$ & \\
\hline Moderate & 267 (69.53\%) & 196 (61.06\%) & & $92(74.80 \%)$ & 163 (64.94\%) & \\
\hline High & $63(16.41 \%)$ & $67(20.87 \%)$ & & $10(8.13 \%)$ & $33(13.15 \%)$ & \\
\hline
\end{tabular}

BMI — body mass index; SBP — systolic blood pressure; DBP — diastolic blood pressure; TC — total cholesterol; HDL-C — high-density lipoprotein cholesterol, LDL-C — low-density lipoprotein cholesterol; TG — triglyceride

Despite the limitations outlined above, our results indicate a problem that is important for CVD prevention programmes. Education is one of the main components of such programmes, but their main objective is to introduce lifestyle changes that reduce exposure to CVD risk factors and consequently, to reduce mortality $[2,24]$. People benefit from knowledge unequally. Knowledge alone is not sufficient for a person to accept a problem as his/her own one, and even more difficult would be to transfer it to changes in lifestyle or to adhere to treatment recommendations. Even if the treatment 
is started, it might not be followed by longitudinal compliance, regular medical checks, and reaching treatment targets, which would finally lead to a reduction of the exposure to CVD risk factors. Indeed, there is evidence that awareness and treatment of CVD risk factors alone are not related to stroke and ischaemic heart disease mortality, but achievement of control is necessary [25]. Our results indicate that a person's education level could affect transfer of knowledge to favourable health behaviours, favourable lifestyle, and consequently a decrease in risk of death. Our findings are consistent with the observations of the increase in health inequalities that are related to education level and which have increased in recent decades despite the introduction of prevention programmes [8, 26]. All of this shows that there is a need to differentiate the means of intervention to ensure that less educated participants will benefit from prevention programmes equally with others. It is likely that in persons with low education, more emphasis on motivation methods is required to achieve treatment targets. The problem seems to be important, and without deeper exploration and finding a satisfactory solution, it could be expected that prevention programmes, which use the same methods despite being addressed to participants with different education levels, would lead to the further increase of health inequality.

\section{CONCLUSIONS}

In a Krakow population characterised by a high proportion of residents with secondary or higher education, the association between knowledge of CVD risk factors and the risk of death depended on sex and education. A lower level of knowledge of risk factors was associated with a higher risk of death only in men with secondary or higher education. This association could not be explained by differences in the exposure to the main CVD risk factors.

\section{Acknowledgements}

The authors express their appreciation to the investigators and to participants of the HAPIEE pilot study.

The HAPIEE pilot study was implemented as part of the research grant of Committee for Scientific Research (4 P05D 019 18) and the research grant of the foundation "The Wellcome Trust" (UK) and approved by Bioethics Committee of the Jagiellonian University.

Conflict of interest: Andrzej Pająk: honorarium from AMGEN, not related with the present work.

\section{References}

1. Rocznik demograficzny 2015. Główny Urząd Statystyczny. Warszawa.

2. Piepoli MF, Hoes AW, Agewall S, et al. 2016 European Guidelines on cardiovascular disease prevention in clinical practice: The Sixth Joint Task Force of the European Society of Cardiology and Other Societies on Cardiovascular Disease Prevention in Clinical Practice (constituted by representatives of 10 societies and by invited experts)Developed with the special contribution of the European Association for Cardiovascular Prevention \& Rehabilitation (EACPR). Eur Heart J. 2016; 37(29): 2315-2381, doi: 10.1093/eurhearti/ehw106, indexed in Pubmed: 27222591.
3. Tunstall-Pedoe H, Kuulasmaa K, Mähönen M, et al. Contribution of trends in survival and coronary-event rates to changes in coronary heart disease mortality: 10-year results from 37 WHO MONICA project populations. Monitoring trends and determinants in cardiovascular disease. Lancet. 1999; 353(9164): 1547-1557, indexed in Pubmed: 10334252.

4. Ford ES, Ajani UA, Croft JB, et al. Explaining the decrease in U.S. deaths from coronary disease, 1980-2000. N Engl J Med. 2007; 356(23): 2388-2398, doi: 10.1056/NEJMsa053935, indexed in Pubmed: 17554120 .

5. Bandosz P, O’Flaherty M, Drygas W, et al. Decline in mortality from coronary heart disease in Poland after socioeconomic transformation: modelling study. BMJ. 2012; 344: d8136-d8136, doi: 10.1136/bmj.d8136.

6. Pająk A, Szafraniec K, Polak M, et al. WOBASZ Investigators. Changes in the prevalence, treatment, and control of hypercholesterolemia and other dyslipidemias over 10 years in Poland: the WOBASZ study. Pol Arch Med Wewn. 2016; 126(9): 642-652, doi: 10.20452/pamw.3464, indexed in Pubmed: 27452484.

7. Szymczuk E, Zajchowska J, Dominik A, et al. Media jako źródło wiedzy o zdrowiu. Medycyna Ogólna i Nauki o Zdrowiu. 2011; 17: 165-168.

8. Wojtyniak B. Choroby układu krążenia jako priorytet zdrowia publicznego; Polska, Europa. In: Szymborski J, Strzelecki Z. Zachorowalność i umieralność na choroby układu krążenia a sytuacja demograficzna Polski. Rządowa Rada Ludnościowa, Warszawa. 2015.

9. Pednekar MS, Gupta R, Gupta PC. Illiteracy, low educational status, and cardiovascular mortality in India. BMC Public Health. 2011; 11: 567, doi:10.1186/1471-2458-11-567, indexed in Pubmed: 21756367.

10. Beauchamp A, Peeters A, Wolfe R, et al. Inequalities in cardiovascular disease mortality: the role of behavioural, physiological and social risk factors. J Epidemiol Community Health. 2010; 64(6): 542-548, doi: 10.1136/jech.2009.094516, indexed in Pubmed: 19825786.

11. Tillin T, Chaturvedi N, Forouhi NG, et al. Cardiovascular disease mortality in relation to childhood and adulthood socioeconomic markers in British South Asian men. Heart. 2008; 94(4): 476-481, doi: 10.1136/hrt.2006.109165, indexed in Pubmed: 17646197.

12. Kozakiewicz K, Podolecka E, Kwaśniewska M, et al. Association between socioeconomic status and cardiovascular risk. Kardiol Pol. 2016; 74(2): 179-184, doi: 10.5603/KP.a2015.0139, indexed in Pubmed: 26202533.

13. CSDH (2008). Closing the gap in a generation: health equity through action on the social determinants of health. Final Report of the Commission on Social Determinants of Health. World Health Organization Geneva.

14. Pająk A, Podolec P, Kopeć G, et al. Polish forum for prevention guidelines on psychosocial cardiovascular disease risk factors. Kardiol Pol. 2009; 67(9): 1048-1051, indexed in Pubmed: 19938366.

15. Pająk A. Psychospołeczne i żywieniowe czynniki ryzyka chorób układu krążenia. Założenia i cele projektu oraz metody badania przekrojowego. (Psychosocial and nutritional cardiovascular disease risk factors - logitudional study. Assumptions, goals and methods of the screening survey). Przegl Lek. 2002; 59: 993-998.

16. Winham DM, Jones KM. Knowledge of young African American adults about heart disease: a cross-sectional survey. BMC Public Health. 2011; 11: 248, doi: 10.1186/1471-2458-11-248, indexed in Pubmed: 21504588.

17. Tedesco LM, Di Giuseppe G, Napolitano F, et al. Cardiovascular diseases and women: knowledge, attitudes, and behavior in the general population in Italy. Biomed Res Int. 2015; 2015: 324692, doi: 10.1155/2015/324692, indexed in Pubmed: 25699272.

18. Bielecki W, Kaczmarczyk-Chałas K, Piwońska A, et al. Świadomość zasad zapobiegania chorobom układu krążenia w populacji 
dorosłych mieszkańców Polski. Wyniki programu WOBASZ. Kardiol Pol. 2005; 63(Suppl. 4): 677-681.

19. Pikala M, Kaleta D, Bielecki W, et al. Awareness of cardiovascular prevention methods among residents of post-communist Polish provinces with highest mortality rates. Cent Eur J Public Health. 2011; 19(4): 183-189, indexed in Pubmed: 22432391.

20. Séguro F, Taraszkiewicz D, Bongard V, et al. Ignorance of cardiovascular preventive measures is associated with all-cause and cardiovascular mortality in the French general population. Arch Cardiovasc Dis. 2016; 109(8-9): 486-493, doi: 10.1016/j. acvd.2016.02.006, indexed in Pubmed:27342804.

21. Mosca L, Mochari-Greenberger H, Dolor RJ, et al. Twelve-year follow-up of American women's awareness of cardiovascular disease risk and barriers to heart health. Circ Cardiovasc Qual Outcomes. 2010; 3(2): 120-127, doi: 10.1161/CIRCOUTCOMES.109.915538, indexed in Pubmed: 20147489.

22. Waśniowska A, Kopeć G, Szafraniec K, et al. Assessment of knowledge about cardiovascular disease risk factors in residents of Małopolska Province, Poland - Małopolska Cardiovascular Preventive Intervention Study (M-CAPRI). Ann Agr Env Med. 2017, doi: 10.5604/12321966.1228400.

23. Lynch EB, Liu K, Kiefe CI, et al. Cardiovascular disease risk factor knowledge in young adults and 10-year change in risk factors: the Coronary Artery Risk Development in Young Adults (CARDIA) Study. Am J Epidemiol. 2006; 164(12): 1171-1179, doi: 10.1093/aje/kwj334, indexed in Pubmed:17038418.

24. Pająk A, Windak A. Zdążyć przed epizodem. Polskie Forum Profilaktyki. 2005; 1: 3-5.

25. Shuaib FM, Durant RW, Parmar G, et al. Awareness, treatment and control of hypertension, diabetes and hyperlipidemia and area-level mortality regions in the Reasons for Geographic and Racial Differences in Stroke (REGARDS) study. J Health Care Poor Underserved. 2012; 23(2): 903-921, doi:10.1353/hpu.2012.0045, indexed in Pubmed: 22643632.

26. Donkin A, Goldblatt P, Lynch K. Inequalities in life expectancy by social class, 1972-1999. Health Stat Q. 2002; 15: 5-15.

Cite this article as: Waśniowska A, Kozela M, Podolec P, Pająk A. Knowledge of cardiovascular disease risk factors and the risk of death in middle-aged residents of Krakow. Kardiol Pol. 2017; 75(4): 386-394, doi: 10.5603/KP.a2016.0180.

Serdecznie zapraszamy na

\title{
KONFERENCJĘ SEKCJI NIEWYDOLNOŚCI SERCA PTK „Postępy w terapii niewydolności serca 2017",
}

\author{
która odbędzie się w dniach 2-3 czerwca 2017 roku \\ w Hotelu Andersia w Poznaniu.
}

Tematem wiodącym Konferencji będą nowości w leczeniu niewydolności serca, implementacja zeszłorocznych zaleceń ESC w praktyce klinicznej oraz dotychczasowe doświadczenia z nowymi lekami.

Program obejmie ponadto wszystkie najważniejsze aspekty leczenia chorób towarzyszących

i rehabilitacji pacjentów z niewydolnością serca.

Poziom naukowy Konferencji zagwarantują najwybitniejsi specjaliści

z poszczególnych dziedzin z całej Polski.

Szczegółowy program oraz rejestracja na stronie internetowej: niewydolnoscserca2017.ptkardio.pl 


\title{
Wiedza o czynnikach ryzyka chorób sercowo-naczyniowych a ryzyko zgonu u mieszkańców Krakowa w wieku średnim
}

\author{
Anna Waśniowska ${ }^{1}$, Magdalena Kozela², Piotr Podolec ${ }^{3}$, Andrzej Pająk ${ }^{2}$ \\ ${ }^{1}$ Oddział Szybkiej Diagnostyki, Krakowski Szpital Specjalistyczny im. Jana Pawła II, Kraków \\ 2Zakład Epidemiologii i Badań Populacyjnych, Instytut Zdrowia Publicznego, Uniwersytet Jagielloński, Collegium Medicum, Kraków \\ ${ }^{3}$ Klinika Chorób Serca i Naczyń, Uniwersytet Jagielloński, Collegium Medicum, Krakowski Szpital Specjalistyczny im. Jana Pawła II, Kraków
}

\section{Streszczenie}

Wstęp: Dostarczanie informacji o czynnikach ryzyka chorób sercowo-naczyniowych (CVD) jest jedną z głównych składowych programów prewencji, których celem jest redukcja narażenia na te czynniki oraz zmniejszenie występowania CVD i umieralności z ich powodu. Jednak niewiele jest dowodów na występowanie związku między wiedzą o czynnikach ryzyka CVD a ryzykiem zgonu.

Cel: Celem niniejszego badania była ocena związku między wiedzą na temat czynników ryzyka CVD a ryzykiem zgonu ze wszystkich przyczyn w populacji mieszkańców Krakowa w wieku średnim oraz ocena, czy związek ten zależy od wykształcenia badanych osób.

Metody: Przeprowadzono badanie kohortowe, w którym czas obserwacji prospektywnej wynosił 15 lat. Do badania zakwalifikowano 3544 osoby, w wieku 45-64 lat, na stałe zameldowane w Krakowie. Wiedzę na temat czynników ryzyka CVD oceniono podczas wywiadu przeprowadzonego przez ankietera, za pomocą 15 pytań zawartych w standardowym kwestionariuszu. Informacje o zgonach u badanych osób i dacie ich wystąpienia otrzymano z rejestru mieszkańców miasta Krakowa. Wyniki zaprezentowano w postaci rozkładów badanych cech. Istotność różnic oceniono za pomocą testu $\chi^{2}$. Prawdopodobieństwo przeżycia przedstawiono w postaci krzywych Kaplana-Meiera, a współczynniki ryzyka z przedziałami ufności (HR, 95\% Cl) obliczono za pomocą wieloczynnikowej analizy przeżycia Coxa. Istotność statystyczną przyjęto na poziomie $p<0,05$.

Wyniki: W badaniu wzięło udział 1152 mężczyzn i 1158 kobiet. Uczestnictwo było porównywalne wśród mężczyzn i kobiet, odpowiednio: 66\% i 65\%. Tylko 39\% mężczyzn i 34\% kobiet miało wykształcenie niższe niż średnie. W porównaniu z kobietami, mężczyźni częściej pozostawali w związkach małżeńskich i częściej byli aktywni zawodowo. Większość uznanych czynników ryzyka było prawidłowo identyfikowanych przez co najmniej 90\% badanych, jednocześnie znaczna część badanych osób nieprawidłowo wskazywała na czynności obniżające ryzyko CVD lub na stany niskiego ryzyka CVD jako usposabiające do wystąpienia zawału serca. Średni czas obserwacji prospektywnej wynosił 14,35 roku (odstęp międzykwartylowy: 14,30-14,39). Łącznie analizą objęto 31188 osobolat obserwacji. Odnotowano 211 zgonów wśród mężczyzn i 96 zgonów wśród kobiet. Po uwzględnieniu wpływu wieku mężczyźni z niskim poziomem wiedzy o czynnikach ryzyka CVD charakteryzowali się wyższym ryzykiem zgonu o 40\% w porównaniu z mężczyznami z wysokim poziomem wiedzy. Zależność pozostawała istotna po uwzględnieniu wpływu stanu cywilnego i aktywności zawodowej. Jednak po uwzględnieniu wpływu wieku i wykształcenia zależność między wiedzą dotyczącą czynników ryzyka a ryzykiem zgonu nie była istotna. Po wykonaniu analizy w warstwach wykształcenia stwierdzono odwrotną zależność między ryzykiem zgonu a poziomem wiedzy dotyczącej czynników ryzyka u mężczyzn z wykształceniem średnim lub wyższym. W tej grupie mężczyźni z niskim poziomem wiedzy na temat czynników ryzyka CVD charakteryzowali się o 60\% wyższym ryzykiem zgonu niż mężczyźni z wysokim poziomem wiedzy. Ponadto w tej grupie różnice w ekspozycji na czynniki ryzyka przemawiały na korzyść mężczyzn z większą wiedzą o czynnikach ryzyka CVD, aczkolwiek zależność ta była nieistotna. Umieralność nie miała związku z poziomem wiedzy o czynnikach ryzyka CVD u kobiet i u mężczyzn z niższym wykształceniem.

Wnioski: W populacji mieszkańców Krakowa, która charakteryzuje się wysokim odsetkiem osób ze średnim lub wyższym wykształceniem, związek wiedzy na temat czynników ryzyka CVD i ryzyka zgonu był zależny od płci oraz wykształcenia. Niski poziom wiedzy o czynnikach ryzyka CVD wiązał się z wyższym ryzykiem zgonu tylko u mężczyzn, którzy mieli średnie lub wyższe wykształcenie. Słowa kluczowe: czynniki ryzyka, wykształcenie, badanie kohortowe

Kardiol Pol 2017; 75, 4: 386-394

\section{Adres do korespondencji:}

lek. Anna Waśniowska, Oddział Szybkiej Diagnostyki, Krakowski Szpital Specjalistyczny im. Jana Pawła II, ul. Prądnicka 80, 31-202 Kraków, e-mail: anwasniowska@gmail.com Praca wpłynęła: 08.08.2016r. Zaakceptowana do druku: $08.11 .2016 \mathrm{r}$. Data publikacji AoP: 16.12.2016 r. 